\title{
ANALISIS HUKUM \\ TERHADAP PERLINDUNGAN KONSUMEN PRODUK PASAR MODAL DI INDONESIA
}

\author{
Hamzah $^{1}$
}

\begin{abstract}
Consumer protection is an important issue in commercial domain. Consumer goods and services should have been protected. The most known is consumer goods protection. This article deals with consumer securities protection. Consumer securities protection has been applied in United States due to financial crisis, including fraud. Indonesia has experienced one of tremendous financial fraud in Bank Century-Antaboga. The case shows that separated surveillence on financial industry has weakness, instead of the integration of financial industry. The role of authority is influential in governing banking-securities industry. In Bank Century-Antaboga case give us a factual absence of disclosure in offering and selling the securities instrument. Otoritas Jasa Keuangan (OJK) should play its role to the application of disclosure principle, otherwise the Bank CenturyAntaboga case will occur again.
\end{abstract}

\section{Kata Kunci: Perlindungan Konsumen, Produk Pasar Modal, Otoritas}

\section{Pendahuluan}

Industri keuangan merupakan industri jasa yang terus mengembangkan inovasi produknya. Industri pasar modal dengan instrumen derivatif dan sekuritisasi, perbankan dengan produk simpanan yang dikombinasi dengan asuransi, asuransi dengan unit linknya, dan lain sebagainya. Industri keuangan di Indonesia terus mengalami perkembangan. Perusahaan-perusahaan dari negara-negara asing masuk ke Indonesia memperdagangkan produk-produk keuangannya. Aktivitas perusahaan-perusahaan asing tersebut juga diikuti oleh perusahaan-perusahaan domestik. Dapat dikatakan bahwa perkembangan yang terjadi di dunia juga berpengaruh di Indonesia. Integrasi industri keuangan memang sudah menjadi suatu kenyataan.

Industri pasar modal menjadi salah satu komponen penting dalam sistem keuangan suatu negara. Di luar perbankan, industri pasar modal mengelola dana dalam jumlah yang signifikan. ${ }^{2}$ Undang-Undang RI Nomor 8 Tahun 1995 Tentang Pasar Modal menyebutkan bahwa pasar modal merupakan sarana untuk melakukan demokratisasi ekonomi. Pernyataan ini mengimplikasikan perlunya perlindungan hukum

\footnotetext{
${ }^{1}$ Dosen tetap Fakultas Hukum Universitas Lampung.

${ }^{2}$ Yunus Husein mencatat sektor perbankan menguasai 93\% aset keuangan di Indonesia, selebihnya dikuasai oleh asuransi, pasar modal, dana pensiun. Yunus Husein, Privasi Versus Kepentin-gan Umum, Program Pascasarjana, Fakultas Hukum, Universitas Indonesia, 2003, hal. 1.
}

bagi investor pasar modal. Kebutuhan ini merupakan suatu keniscayaan mengingat di pasar modal terdapat dana kelolaan yang besar.

Pengaturan pasar modal pada awalnya bertum- pu pada pengembangan (establishment) dan perlindungan hukum secara umum.Pasar modal Indonesia tidak terlepas dari perkembangan yang terjadi di dunia. Peran Otoritas Jasa Keuangan (OJK) dalam pembuatan regulasi, pengawasan dan penegakan peraturan menjadi lebih penting pada masa kini. Eksistensi Otoritas Jasa Keuangan (OJK) didasarkan pada pelaksanaan perannya dalam membina, mengawasi pasar modal. Respon terhadap perkembangan dan kasus yang terjadi menggambarkan bagaimana Otoritas Jasa Keuangan (OJK) menjalankan perannya dan dampak nyata terhadap pasar modal.

Peran Otoritas Jasa Keuangan (OJK) pada saat melakukan pengawasan dan penegakan peraturan tidak terlihat dalam kasus Bank Century-Antaboga. Ketika nasabah Bank Century dibujuk untuk memindahkan dananya ke produk discretionary fund $^{3}$ Antaboga

\footnotetext{
${ }^{3}$ Discretionary fund merupakan instrumen pasar modal yang pengelolaan dana diserahkan kepada fund manager. Some fund managers may have an incentive to use their discretion to delay realizing investments to retain control of fund capital. For example, in the context of the start-up technology company, fund managers may simply fail to take the company public to delay booking profits and avoid the mandatory distribution provision. As shall be discussed in more detail shortly, fund managers traditionally receive management fees which are a function of the amount committed by investors to the fund. These manage-ment fees can be a substantial part of the fund managers' compensation. As such, the fund ma-
} 
suatu produk pasar modal, agen produk tidak memberikan informasi yang lengkap kecuali mengenai perolehan keuntungan. Ketika Bank Century dilikuidasi, PT Antaboga Delta Sekuritas juga menjadi pailit, karena sahamnya sebagian besar dimiliki oleh PT. Bank Century. Kekacauan terjadi. Nasabah Bank Century tidak seluruhnya memperoleh jaminan dari Lembaga Penjamin Simpanan (LPS). Yang lebih mengenaskan adalah nasib nasabah PT Antaboga Delta Sekuritas (ADS) yang kehilangan dananya akibat fraud yamg terjadi di PT Bank Century.

Hal lain yang menjadi isu penting terhadap keniscayaan perlindungan hukum bagi investor adalah rentannya pasar modal dari krisis. Perdebatan berada dalam ranah seberapa perlunya perlindungan investor dan bagaimana melakukannya serta sumber dananya. Krisis bagian yang tidak terlepaskan dari industri pasar modal dan industri keuangan pada umumnya. Amerika Serikat, negara yang telah memiliki pasar modal yang mapan, pun harus melewati dan mengatasi masalah krisis. Krisis merupakan pelajaran. Krisis melahirkan kesadaran perlunya pengaturan berkenaan dengan krisis. ${ }^{4}$ Krisis menjadi bagian dari industri pasar modal dan industri keuangan pada umumnya. Krisis keuangan di Amerika Serikat yang kemudian mendunia terjadi pada tahun1930, ${ }^{5}$ terulang lagi pada 1997 dan $2008 .^{6}$

nagers might delay liquidating a position in order to continue to receive a lucrative management fee for this investment or to meet other objectives, like tax benefits or fund benchmarks, which are not neces-sarily in the best interests of investors.Delayed exit from investments might also help fund managers ability to "control" performance data critical to fundraising for the next fund. As long as investments have not been brought to market, fund managers have substantial control over information about the performance of fund invest-ments and, thus, valuation of un-exited investments. Delayed distribution, therefore, can create room for unscrupulous fund managers to keep perform-ance measures undercover or, worse, overstate performance data. If fund managers can credibly argue that unrealized investments have performed well, they can more easily raise capital for the next fund. At the same time, attempts to evade the mandatory distribution require-ments could have exactly the opposite effect on fund managers. That is, it could be the case that the mandatory distribution provisions encourage fund managers to speed up their exit strategy from portfolio companies. Fund managers who are short on free cash flow may want to bring their fledgling young companies to market as quickly as possible because of the mandatory distribution requirement. They may push for an initial public offering, even though external conditions are far from ideal-markets may be tightening, for example. Lee Harris, " A Critical Theory Of Private Equity," Article Delaware Journal of Corporate Law, 2010, hal. 277-278.

${ }^{4}$ Eric C. Chaffee," A Moment Of Opportunity: Reimagining International Securities Regulation In The Shadow Of Financial Crisis," Nexus: Chapman's Journal of Law \& Policy Volume 15 2009-2010, hal. 34.

${ }^{5}$ GreatDepression of the 1930 's, like *73many if not all of the previous panics, included powerful industrialists, large speculators natural calamities, and fraud schemes at their cores. Arguably, the 1930 's reflected the confluence of investor crisis (margin cal-
Pengalaman Amerika menghadapi krisis pada tahun 1930 telah mendorong urgensi pengaturan pasar modal khususnya mengenai perlindungan investor.

In the wake of this crisis, just as in the aftermath of the banking collapse of the 1930s, Congress has an opportunity to restructure a broken finan-cial regulatory system. More than band-aids are required. If the reforms Congress now adopts are to secure a lengthy period of financial stability, as was the case following the New Deal era's reenvisioning of financial regulation, consumer protection cannot continue tobe marginalized.

Eksistensi pasar modal utamanya karena adanya investor. Oleh karena itu, perlindungan investor adalah faktor penting, mungkin salah satu yang terpenting, dalam pengaturan di pasar modal dan industri keuangan pada umumnya. ${ }^{7}$

Untuk memgoptimalkan perlindungan investor, industri pasar modal memerlukan otoritas khusus untuk itu. Krisis di bidang keuangan melahirkan otoritas khusus di masing-masing industri keuangan.

Congress has an opportunity to demonstrate leadership as it considers the creation of a new, independent agency whose sole mission is to protect consumers of financial products from the abuses which contributed to the present financial crisis. The prospect of such a major shift in the allocation of regulatory authority sets the stage for heated debate between consumer protection ad-

ls), personal and family insolvencies, customer runs on banks, and a withdrawal of consumer buying with no counterbalance of new business investment spending. According to Ben Bernanke, "the effects of this credit squeeze on aggregate demand helped convert the severe but not unprecedented downturn of 1929-30 into a protracted depression." Bernanke also notes that the Great Depression negative feedback loop included substantial defaults by home owners; in none of the 22 cities were defaults less than $21 \%$ of all homeowners (national home ownership rate was 50\%) and half of the cities experienced over $38 \%$ of all mortgages with defaults. Roger L. Torneden, Ph.D.,"67 Will Devaluation Of Dollar Pull The U.S. Out Of Depression Once Again?" The 80th Anniversary of the Great Crash of 1929: Law, Markets and the Role of the State,Nexus: Chapman's Journal of Law \& PolicyVolume 15, 2009-2010, hal. 73.

${ }^{6}$ Notably, the financial crisis that began in 2008 has been referred to as the "most severe financial crisis since the Great Depres-sion," the "Great Recession," and even a depression itself. Put simply, regulatory fragmentation creates a race-to-the-bottom in any system of securities regulation that generates dire results. Although some benefits may exist to regulatory competition, these benefits are outweighed by this reality. Chaffee,"Contemplating The Endgame:...," hal. 589.

${ }^{7}$ Malcolm K. Sparrow, The Regulatory Craft: Controlling Risks, Solving Problems And Managing Compliance, Washington D.C., Brookings Institution Press, 2000, hal. 17-18. Sparrow menekankan pentingnya keahlian membuat peraturan, melakukan penegakan hukum, serta menyeimbangkan kepentingan investor dan issuer. 
vocates and beneficiaries of the status quo in both the federal regulatory agencies and the financial services industry. ${ }^{8}$

Perlindungan investor disepakati sebagai salah satu muatan hukum yang terpenting. Namun perdebatan mengenai efektivitas pemberian perlindungan investor berada dalam konteks otoritas khusus seperti praktik yang ada saat ini dan sebagiannya mengandalkan otoritas khusus yang mencakup seluruh industri keuangan.

Pada hakikatnya, eksistensi otoritas khusus di bidang pasar modal untuk memberikan perlindungan hukum bagi investor dalam bentuk pembuatan regulasi dan penegakannya. Perlindungan investor merupakan aspek krusial dan vital dalam pengembangan pasar modal suatu negara. Perlindungan investor tidak hanya disandarkan pada hukum perusahaan, tetapi juga regulasi pasar modal. ${ }^{9}$ Keduanya harus ada dan saling melengkapi. Perlindungan investor menggambarkan bagaimana suatu pasar modal dari suatu negara dikelola. Peran otoritas menjadi kunci dalam pelaksanaan perlindungan investor.

\section{PERMASALAHAN}

1. Bagaimanakah Bentuk Perlindungan Konsumen Dan Konsumen Produk Pasar Modal?

2. Bagaimanakah Peran Otoritas Untuk Melakukan Perlindungan Konsumen Produk Pasar Modal?

\section{TUJUAN PENULISAN}

1. Untuk mengetahui dan mengkonstruksikan Perlindungan Konsumen Dan Konsumen Produk Pasar Modal.

2. Untuk mengetahui dan mengkonstruksikan Peran

Otoritas Dalam melakukan Perlindungan Konsumen Produk Pasar Modal

\section{PERLINDUNGAN KONSUMEN DAN KONSUMEN PRODUK PASAR MODAL}

Pada era globalisasi ekonomi atau perdagangan bebas ini, arus barang dan jasa tidak boleh mendapatkan hambatan masuk atau pun keluar. Begitu pula halnya dengan arus modal. Pasar modal secara natural

\footnotetext{
${ }^{8}$ Ann Graham, "The Consumer Financial Protection Agency: Love It Or Hate It, U.S. Financial Regulation Needs It," Article, Symposium: Financial Regulatory Reform: Genesis, Progress, and Impact, Villanova Law Review 2010, hal. 604.

${ }^{9}$ Caspar Rose, "The Challenges Of Quantifying InvestorProtec- tion In A Comparative Context,"European Business Organiza- tion Law Review Vol. 8 2007, hal. 373.
}

merupakan wahana investasi yang pada hakikatnya menjanjikan prospek keuntungan bagi investornya. Pasar modal suatu negara hanya akan mendapatkan arus masuk investasi jika memperdagangkan efek perusahaan yang menjalankan usaha yang berprospek. Pasar modal tersebut harus berjalan teratur, wajar dan efisien. ${ }^{10}$ Untuk itu, pengaturan di bidang pasar modal mencakup

...government intervention aimed at coping with failures in securities market by means of laws, economic policies, administrative orders, and self-regulation. According to studies carried out on the regulation of securities markets from an institutional economics perspective, such as Kahn (1970), Stigler and Friedland (1962), Stigler (1964, 1971) and Peltzman (1976, 1993), securities market public regulation is a necessary and efficient method of dealing with "market failures" if regulatory activities are properly defined and effectively carried out. ${ }^{11}$

Peraturan di bidang pasar modal didisain sebagai bentuk respon terhadap permasalahan yang terjadi di pasar, termasuk krisis.

Perlindungan investor diidentikkan dengan perlindungan konsumen. Bagi sebagian kalangan pasar modal dan industri keuangan pada umumnya investor adalah customer. Oleh sebab itu, perlindungan investor produk pasar modal juga merupakan perlindungan konsumen. Kasus yang terjadi di Amerika Serikat dalam dekade 2000 dan krisis yang terjadi melahirkan pemikiran mengenai perlunya perlindungan konsumen produk pasar modal.

Currently, consumer protection authority in financial services is split between federal and state

\footnotetext{
${ }^{10}$ Professor Coffee has argued that concepts of efficiency, rather than fairness or the prevention of fraud, now provide the principal justification for mandatory disclosure. He contends that in today's markets, the search for information by securities analysts and other market professionals is the "motor force that principally keeps the market efficient." Under Coffee's analysis, mandatory disclosure reduces the search costs for market professionals, thereby increasing the aggregate amount of research and verification that will be provided. He further argues that empirical data suggest that the mandatory disclosure system has reduced price dispersion in returns on securities investments. As a consequence, the market has become more "efficient" in the sense that its allocative efficiency has improved - capital is now more correctly priced than it would be without mandatory disclosure. Jeffrey D. Bauman," Loss And Seligman On Securities Regulation: An Essay For Don Schwartz Securities Regulation,” Book Review Georgetown Law Journal June, 1990, hal. 1768.

${ }^{11}$ Jingyun Ma, Fengming Song, Zhishu Yang," The DualRole Of The Government: SecuritiesMarketRegulationin China 1980- 2007, Journal of Financial Regulation and Compliance Volume 18, 2010, hal. 18.
} 
governments. Traditionally, consumer protection, including in financial services, was part of the general police power of the states. States generally focused on antifraud and unfair-and-deceptive acts and practices enforcement through litigation, but also imposed some product and practice prohibitions and disclosure requirements.Increasing ly, though (with the exclusion of insurance), it has been federalized as the result of preemption, either by legislation, agency regulation or courtrulings. While states have become increasingly excluded from consumer financial services regulation, the preempted state protections have not been replaced with equivalent federal protections. ${ }^{12}$

Perlindungan konsumen produk pasar modalbergantung pada pengawasan dan penegakan peraturan pasar modal oleh otoritas pasar modal.

Paling tidak ada empat hal yang perlu mendapat perhatian dalam pengaturan perlindungan konsumen yaitu "[1] consumer protection is a so-called 'orphan' mission; [2] consumer protection conflicts with, and is subordinated to, safety-and-soundness concerns;

[3] no agency has developed an expertise in consumer protection in financial services, and; [4] regulatory arbitrage of the current system fuels a regulatory race to the bottom. ${ }^{\prime 13}$ Amerika Serikat mengakui perlunya perlindungan konsumen produk pasar modal dan produk keuangan pada umumnya. Paradigma pengaturan perlindungan konsumen berkenaan dengan konsumen barang.

Undang-Undang RI Nomor 8 Tahun 1999 Tentang Perlindungan Konsumen mencakup hal-hal sebagai berikut definisi, pelaku usaha, klausul baku,perbuatan yang dilarang badan perlindungan konsumen, tanggung jawab pelaku usaha, pembinaan dan pengawasan, lembaga perlindungan konsumenswadaya masyarakat, penyelesaian sengketa, badan penyelesaian sengketa, penyidikan, sanksi. ${ }^{14}$ Kerangka UUPK menunjukkan bahwa Indonesia berusaha menjangkau perlindungan konsumen barang dan jasa.

Perlindungan konsumen menurut UUPK Pasal 3 bertujuan:

\footnotetext{
${ }^{12}$ Prof. Adam J. Levitin, "The Consumer Financial Protection Agency,"American Bankruptcy Institute Journal October, 2009, hal. 65 .

${ }^{13}$ Kyle C. Worrell, "Crisis As A Catalyst For Federal Regulation In Financial Markets: The Rise Of The Consumer Financial Protection Bureau," Article Citizens Divided on Citizens United: Campaign Finance Reform and the First Amendment Nexus: Chapman's Journal of Law \& Policy 2010-2011, hal. 196.

${ }^{14}$ Undang-Undang RI Nomor 8 Tahun 1999 Tentang Perlindungan
}

a. meningkatkan kesadaran, kemampuan dan kemandirian konsumen untuk melindungi diri;

b. mengangkat harkat dan martabat konsumen dengan cara menghindarkannya dari ekses negatif pemakaian barang dan/atau jasa;

c. meningkatkan pemberdayaan konsumen dalam memilih, menentukan dan menuntut hak-haknya sebagai konsumen;

d. menciptakan sistem perlindungan konsumen yang mengandung unsur kepastian hukum dan keterbukaan informasi serta akses untuk mendapatkan informasi;

e. menumbuhkan kesadaran pelaku usaha mengenai pentingnya perlindungan konsumen sehingga tumbuh sikap yang jujur dan bertanggung jawab dalam berusaha;

f. meningkatkan kualitas barang dan atau jasa yang menjamin kelangsungan usaha produksi barang dan atau jasa, kesehatan, kenyamanan, keamanan, dan keselamatankonsumen.

Tujuan keberadaan UUPK mengimplikasikan perilaku etis dan moralistis melalui diseminasi informasi secara jujur dan lengkap mengenai produk pasar modal yang ditawarkan kepada investor. Inti dari transaksi produk pasar modal didasarkan pada pelaksanaan keterbukaan informasi.

Perlindungan konsumen produk pasar modal bertumpu pada pelaksanaan keterbukaan informasi.

Consumer protection in financial services currently involves a mixture of disclosure requirements, supervisoryfeedback, product and practice prohibitions, and enforcement actions. The centerpiece of the currentregime, however, is disclosure. The basic conceit of consumer financial services regulation is that themarket is the best guarantor of consumer protection. Markets rely on information. If all material informationis readily available to consumers in a form they can easily process, then consumers will be able to make intelligent, informed decisions, which will presumably maximize consumer welfare and discipline product andpractice offerings. The disclosure regime is policed through supervisory feedback, enforcement actions, and occasionally prohibitions on terms, products and practices that are deemed inherently unfair and deceptive, and therefore not conducive to a disclosure-based regime. Disclosure, though, is the heart of consumer protection; other regulatory tools are merely designed to enhance its operation..$^{15}$

\footnotetext{
${ }^{15}$ Ibid., hal. 65.
} 
Perlindungan investor atau konsumen produk pasar modal didasarkan pada pelaksanaan prinsip keterbukaan, pengawasan otoritas, kualitas produk investasi, pelarangan dan penegakan peraturan.

Pelaksanaan prinsip keterbukaan merupakan inti dari perlindungan investor atau konsumen produk pasar modal. ${ }^{16}$ Namun hal itu sangat bergantung pada kelengkapan, akurasi dan ketepatan waktu penyampaiannya. Bila aspek tersebut tercakup dalam pelaksanaan prinsip keterbukaan, dapat dikatakan bahwa informasi yang disampaikan dapat dipergunakan dalam pengambilan keputusan oleh investor.

Tidak mudah menegakkan peraturan pelaksanaan prinsip keterbukaan. Perdebatan seberapa jauh keterbukaan tersebut mencakup kepentingan issuer dan konsumen atau investor pasar modal.

The 2000's were plagued by lenders in a financial system who relied on inefficiency and ineffectual disclosure. Predatory lending practices, highinterest rates on credit cards, and astronomical penalty fees, stifled consumers under a federal regulatory regime which favored profit over protection. While it may have made sense to incentivize responsibility by punishing irresponsible behavior through imposition of high interestrates and fees, these practices and policies of banks and lenders were bankrupting consumers. Even more egregious, consumers who could afford it the least were paying the most. ${ }^{17}$

Pelaksanaan prinsip keterbukaan menjadi isu yang paling mendapat perhatian dalam ranah kekonsumenan.

Pelaksana perlindungan konsumen produk pasar modal sepertinya tidak dapat mengandalkan hanya Otoritas Jasa Keuangan (OJK) yang mengurusi semua sektor keuangan kecuali perbankan.

There was no single entity to oversee consumer protection issues, and the regulatory structure was failing on multiple levels. A variety of regulatory agencies existed which sought to address a combination of issues, and were sometimes caught balancing competing interests of safety and soundness against consumer protection. These problems were inherently structural, and effective reform must substantially repair the existing regulatory agencies or replace the whole balkanized structure. ${ }^{18}$

\footnotetext{
${ }^{16}$ Bismar Nasution. Keterbukaan Dalam Pasar Modal Indonesia, Jakarta: Fakultas Hukum Universitas Indonesia, 2001, hal.1.

${ }^{17}$ Worrel. Op.cit., hal. hal. 196.

${ }^{18} \mathrm{Ibid}$.
}

Tidak mudah melaksanakan prinsip keterbukaan. Pihak konsumen menuntut keterbukaan sepenuhnya dan tidak mengetahui seberapa korektif atau lengkap- nya suatu informasi mengenai produk yang disampai- kan kepada konsumen produk pasarmodal.

\section{PERAN OTORITAS PERLINDUNGAN KONSUMEN PRODUK PASAR MODAL}

Perlindungan konsumen merupakan salah satu isu hukum yang penting dalam konstelasi pengaturan hukum di dunia saat ini. Konsep perlindungan konsumen mencakup aspek pengaturan dan penegakannya. ${ }^{19} \mathrm{Ti}-$ dak mudah untuk melakukan keduanya dalam konteks saat ini dimana produsen bukan merupakan kekuatan tunggal. Konsumen dapat melakukan "perlawanan" terhadap kerugian yang dialaminya melalui media massa atau pun membangun opini melalui jejaring sosial. Yang pasti perlindungan konsumen merentang dari pembuatan hukum hingga penegakannya.

... the term "consumer protection" to refer to laws, regulations, and enforcement actions that aim to protect consumers both from unsafe or potentially unsafe products and services and from products, services, or sales methods designed to exploit informational or bargaining-power asymmetries, including cognitive biases and lack of self-control, such that consumers do not receive what they expected from their bargains. Thus, consumer protection is both about prohibiting or restricting dangerous products (such as leadbased paint or non-purchase-money security interests in consumer goods) and leveling the playing field between consumers and the professional sellers (or purchasers) of goods and services. ${ }^{20}$

Konsumen berhak memperoleh barang atau jasa yang bagus, tidak mengandung bahaya atau dapat merugikan. Untuk barang yang tidak bagus, konsumen dapat melakukan klaim melalui layanan purna jual. Untuk jasa yang menimbulkan kerugian selayaknya konsumen memperoleh penggantian.

Perlindungan konsumen produk pasar modal dilakukan oleh Otoritas Jasa Keuangan (OJK) dan Lembaga Perlindungan Konsumen Indonesia (YLKI). ${ }^{21}$

\footnotetext{
${ }^{19}$ Adam J. Levitin,"Hydraulic Regulation: Regulating Credit Markets Upstream," Yale Journal on Regulation Summer 2009, hal. 148.

${ }^{20}$ Ibid., hal. 148.

${ }^{21}$ YLKI merupakan lembaga swadaya masyarakat yang lebih memiliki kekuatan menekankan produser dan pemerintah terhadap persoalan yang dialami masyarakat konsumen. YLKI bukan lembaga otoritas yang memiliki kewenangan untuk melakukan tindakan represif.
} 
Industri perbankan memiliki Lembaga Penjaminan Simpanan (LPS) yang akan membayar uang nasabah, ketika bank dilikuidasi. Industri pasar modal tidak memiliki lembaga yang demikian. Kasus Bank Century-Antaboga memperlihatkan bahwa investor pasar modal tidak mendapatkan penggantian seperti nasabah bank ketika terjadi fraud.

The financial regulation which spawned out of the Great Depression led to nearly 50 years without a financial crisis. The regulations included feder-al deposit insurance, securities regulations, and banking supervision. However, dissatisfied with the status quo and considering the burden of regulatory weight as an insuperable impediment to efficient capital markets, financial firms and policy makers began their campaign for deregulation. The lessons of the past were soon forgotten. ${ }^{22}$

Krisis merupakan bagian yang tidak terlepaskan dari industri keuangan dan industri keuangan pada umumnya. Peran otoritas merupakan aspek kunci dalam penanganan krisis dalam rangka menjaga pasar modal untuk tetap berjalan tertib, teratur dan wajar. Krisis melahirkan kesadaran mengenai pentingnya regulasi dan penegakan peraturan yang sesuai dengan situasi dan kondisi krisis.

Dalam konstelasi otoritas di bidang keuangan di Indonesia, perlindungan konsumen berada dalam ranah kerja masing-masing. LPS dan Bank Indonesia menangani perlindungan konsumen jasa perbankan. Dalam industri pasar modal, Badan Pengawas Pasar Modal Dan Lembaga Keuangan Otoritas Jasa Keuangan (OJK) yang memainkan peran tersebut. Peran tersebut diwujudkan Otoritas Jasa Keuangan (OJK) melalui pengawasan dan penegakan ketentuan hukum di bidang pasar modal dalam keadaan krisis maupun normal.

Kasus skandal keuangan di Amerika Serikat mendorong senat untuk melahirkan legislasi untuk melindungi konsumen produk keuangan, termasuk pasar modal, yang dikenal dengan nama Doddfrank Act. Ketentuan tersebut mendorong perdebatan mengenai kebutuhan lembaga khusus menangani perlindungan konsumen produk pasar modal dan industri keuangan pada umumnya. Apakah Indonesia memerlukan lembaga baru bagi perlindungan konsumen produk keuangan dan pasar modal pada khususnya? Jawabannya bergantung pada efektivitas penanganan masalah oleh lembaga yang ada dengan mengacu pada hukum yang berlaku.

\footnotetext{
${ }^{22}$ Worrel. Op.cit., hal. 197-198.
}

Di Amerika Serikat perlindungan konsumen merupakan ranah kerja Office of the Comptroller of the Currency $(O C C){ }^{23}$ Eksistensi lembaga ini mendapatkan kritik. Tindakan preemptif OCC ternyata malah melemahkan perlindungan konsumen produk keuangan.

In their 2008 article, Bar-Gill and Warren argued that a new consumer financial protection agency was needed because, among other reasons, existing federal financial regulators were insufficiently motivated to focus on consumer protection. BarGill and Warren also alleged that the aggressivepreemption of state consumer financial protection laws by the Office of the Comptroller of the Currency (OCC) in the 2000s weakened consumer financial protection at the state level. Throughoutthe past decade, consumer advocates, attorneys general, and academics have agreed, criticizing the OCC andthe Office of Thrift Supervision (OTS) for their use of preemption to prevent states from crackingdown on predatory lending. ${ }^{24}$

Di lain sisi, OCC dan lembaga lain yang mengurusi perlindungan konsumen berargumentasi bahwa keberadaan dan tindakan mereka memang dibutuhkan untuk mendorong efisiensi. Perdebatan mengenai peran dan tindakan lembaga perlindungan konsumen seperti OCC dan badan federal lainnya di Amerika Serikat berkisar pada efektivitas peran lembaga dan penggunaan tindakan preemtif.

For their part, the OCC and other federal regulators have defended theiruse of preemption, argu-ing that the U.S. Constitution requires preemption where state law conflicts with federallaw, and that preemption is an important tool for promoting the efficient operation of credit markets. As developed more fully below, both sides of the debate make a compelling argument, creating apreemption dilemma: preemption of state consumer financial protection laws could both harm and benefitconsumers. ${ }^{25}$

Pelaksanaan perlindungan konsumen produk pasar modal dan keuangan pada umumnya berdampak positif dan negatif.

Pembentukan lembaga baru untuk perlindungan konsumen produk keuangan dan pasar modal menambah biaya. Kebutuhan akan lembaga baru menunjuk-

\footnotetext{
23 Jared Elosta, "Dynamic Federalism And Consumer Financial Protection: How The Doddfrank Act Changes The Preemption Debate," Recent Development, North Carolina Law Review May, 2011, hal. 1274

${ }^{24} \mathrm{Ibid}$., hal. 1274

${ }^{25}$ Ibid., hal. 1274.
} 
kan bahwa sistem hukum yang ada tidak berjalan optimal. Otoritas di bidang keuangan dan pasar modal pada khususnya mampu melaksanakan peran sebagai pengawas, pembina dan sekaligus sebagai lembaga penegakan peraturan. Secara hipotetik, jika peran tersebut berjalan maka tidak dibutuhkan lembaga lain untuk melaksanakan perlindungan konsumen produk keuangan dan pasar modal. Secara hipotetik pula dapat dikatakan bahwa pelaksanaan perlindungan konsumen produk keuangan dan pasar modal pada khususnya berada pada pelaksanaan prinsip keterbukaan informasi. Jika penerapan prinsip keterbukaan informasi dilakukan sesuai dengan hakikatnya yai- tu disampaikan secara lengkap, tepat waktu, akurat dan aksesibilitas kepada semua pihak, maka otoritas dapat memantau perdagangan produk keuangan dan pasar modal pada khususnya.

Dampak positif dari perlindungan konsumen produk pasar modal mencakup beberapa hal seperti persaingan usaha yang sehat dan meningkatkan efisiensi.

There are several economic benefits alleged to result from federal preemption of state regulations of nationalbanks and thrifts. First, preemption can promote competition by preventing states from protecting certainkinds of domestic industries and companies. For example, the OCC has sent letters to stateswarning them of conflicts with federal laws when states have tried to restrict out-of-state national banksfrom selling annuities, acting as fiduciaries, and opening ATMs. Each of these restrictions wouldhave likely caused increased cost or inconvenience to consumers as a result of limiting the ability of outof-state national banks to compete with local banks. Second, as a result of the nature of interstatebanking, various OCC officials have argued for uniform, nationwide banking laws in order to promote efficiencyby reducing compliance costs. A senior economic advisor at the OCC has presented empiricalevidence that preemption has been especially beneficial for smaller interstate national bank holding companies. ${ }^{26}$

Persaingan usaha yang sehat dan efisiensi merupakan dua aspek penting yang selalu berusaha diwujudkan oleh industri keuangan. Persaingan sehat mencakup aspek kejujuran para pelaku usaha dalam menyampaikan informasi dan tidak melansir informasi mengenai perusahaan lain apalagi informasi yang tidak benar atau mengeksploitasi informasi ne- gatif mengenai perusahaan lain. Efisiensi mewujud dalam aspek bahwa informasi yang disampaikan kepada publik merupakan informasi yang decisive bagi pengambilan keputusan.

Di antara industri keuangan, sektor perbankan merupakan sektor yang memiliki infrastruktur untuk perlindungan konsumen. Mulai dari peraturan yang mewajibkan bank melakukan serangkaian tindakan dan prosedur demi menjamin keamanan uang nasabah, hingga lembaga penjamin simpanan.

Although this researcher acknowledged that there are relatively few empirical studies on the costeffects of banking regulations, there is evidence that banks have substantial compliance costs whenthey must respond to state regulation. Even Profes- sors Warren and Bar-Gill, who criticized the ef-fectsof federal preemption over the past decade, have acknowledged that " $[i] n$ an era of interstate banking,uniform regulation of consumer credit products at the federal level may well be moreefficient than alitany of consumer protection rules that vary from state to state. "27

Indonesia pun memiliki infrastruktur untuk melaksanakan perlindungan konsumen sektor perbankan. Namun perlu memisahkan antara aspek politik dan bisnis dalam pelaksanaan perlindungan konsumen perbankan.

Amerika Serikat, dengan sistem negaranya, membagi peran lembaga di tingkat negara dan federal untuk melaksanakan perlindungan konsumen di bidang keuangan, namun regulasinya mencakup skala nasional.

Dodd-Frank creates a structure of "dynamic federalism" in consumer financial protection regulation: it creates a new federal agency charged with protecting consumers and adopting nationwide regulation, and it gives states more powers to protect their own citizens than existed before the legislation. The new relationship that DoddFrank creates between states and the federal government can be seen most clearly in the ways that it helps resolve the preemption dilemma. This dilemma arises because federal preemption of state consumer financial laws does provide consumers with economic benefits, but at the same time, preemption may also hurt consumers. Both sides of the debate about federal preemption that has occurred over the past decade have had an element of truth in their arguments. However, be- 
cause of Dodd-Frank's changes topreemption, the emergence of the $C F P B$, and the new powers that Dodd-Frank provides the states, this debate is now likely to become much less pronounced. ${ }^{28}$

Pembentukan lembaga baru, sepanjang efektif, ditujukan pada optimalisasi perlindungan konsumen produk keuangan dan pasar modal pada khususnya. Amerika Serikat memilih jalan demikian. Mungkin pembentukan lembaga demikian tidak menimbulkan masalah dalam pendanaan operasional lembaganya bagi negara seperti Amerika Serikat yang industri keuangan telah mapan.

Konsumen juga bukan pihak tanpa daya. Konsumen institusi atau negara mampu memiliki posisi tawar yang kuat, namun yang perlu memperoleh perhatian adalah konsumen individual.

The image of the consumer as a sovereign market actor has shaped large parts of European consumer law. The prevailing image of the European consumer in EC law is that of the "average" consumer who is "reasonably well informed and reasonably observant and circumspect"--a concept developed by the European Court of Justice. This average consumer, provided he is adequately informed, is well equipped to address his own needs and preferences and is able to search among the services and products that are publicly available for those that best meet his needs. Of course, what best addresses a consumer's needs differs from consumer to consumer. Such needs can be economic (e.g., getting the best deal for the money), non-economic (e.g., the making of private copies to engage in transformative uses), self-centered, or altruistic. Note that in the European perception the sovereign consumer plays a far more active role than just "consuming." He is an active driver behind the development of the Internal Market and behind a competitive offering of services that responds to the interests of consumers of the European Union. In other words, if the European consumer attaches any value to private copying, it is up to him to make markets deliver information products and services that can be copied for private use. ${ }^{29}$

Perlindungan konsumen merupakan isu sentral dimana hal itu dilaksanakan melalui penyampaian informasi. Konsumen harus memiliki informasi yang valid, lengkap dan jelas mengenai produk. Issuer atau

\footnotetext{
${ }^{28}$ Ibid., hal.1307-1308.

${ }^{29}$ Natali Helberger and P. Bernt Hugenholtz, "No Place Like Home

For Making A Copy: Private Copying In European Copyright Law And Consumer Law," Article Symposium: Copyright, Digital Rights Management Technology, and Consumer Protection, Berkeley Technology Law Journal Summer 2007, hal. 1080-1081.
}

emiten harus menyampaikan informasi selengkapnya mengenai produk pasar modalnya. Dalam konteks ini perlindungan konsumen merupakan pemberdayaan konsumen.

Dalam hubungan produsen-konsumen, konsumen merupakan pihak yang lebih lemah berkenaan dengan penguasaan informasi.

In contrast, proponents of a more interventionist role of the state in consumer matters warn against overestimatingthe self-regulatory powers of the market and emphasize that empowering the consumer is not always sufficient toguarantee an adequate standard of consumer protection. Common justifications for a more activist role ofthe regulator are welfare economics and imbalances in the transactional relationship between consumers andservice providers. Through this lens, the consumer is less the sovereign decision maker and more the structurallyweaker party in commercial negotiations. ${ }^{30}$

Raison d'etre perlindungan konsumen menyangkut penyampaian informasi oleh pihak produsen kepada konsumen. Kedudukan kedua belah pihak tidak setara. Produsen secara alami dan pertimbangan ekonomi akan berusaha menonjolkan informasi kelebihan produknya dan menyembunyikan atau mengaburkan informasi kelemahan atau kekurangan produknya.

Penyampaian informasi ditujukan untuk memberikan gambaran bahwa konsumen membeli barang atau jasa yang diperlukan.

Principle One of the EC's Ten Basic Principles of Consumer Protection in the European Union is: "Buy what you want, where you want." Consequently, consumer law's role is to create the market conditions that allow consumers to "vote with their purse" by rectifying market failures, most notably information asymmetries. Consumer information is an important prerequisite for the sovereign consumer to manage his own affairs. Thus, EU consumer policies focus on consumer empowerment, or "consumer assistance," with minimal intervention, rather than on consumer protection. The better the market serves the interests of consumers, the smaller the role of the legislature can remain. ${ }^{31}$

Informasi yang disampaikan sepatutnya menjadikan konsumen benar-benar mengetahui (caveat emptor) produk yang dibelinya. Konsumen produk pasar modal mengetahui benar risiko produk, perolehan keuntungan dan kredibilitas issuernya.

\footnotetext{
${ }^{30}$ Ibid. hal. 1081-1082.

${ }^{31}$ Ibid., hal. 1081.
} 
Konsumen individual lebih lemah dibandingkan konsumen besar seperti institusi atau negara.

Unlike the sovereign consumer, the weak consumer is less capableof minding his own affairs because he lacks information, education, awareness, or negotiation power. Thus,removing market failures that obstruct the consumer's "right to choice" is not enough to protect the weak consumer. From this perspective, the primary role of consumer law is to intervene where consumers suffer harm or aretreated unfairly by suppliers in business relationships.Playing a central role in European consumer law, corrective justice is also an important justification underlyingconsumer sales law, the rules on unfair commercial business practices, and the rules on contracts. ${ }^{32}$

Eksistensi hukum perlindungan konsumen le- bih ditujukan pada konsumen individual atau untuk mempersempit kesejangan hubungan atau kekuatan antara produsen dan konsumen. Pemberian ganti kerugian menjadi sarana untuk mengembalikan kedudukan konsumen yang dirugikan atau paling tidak mengurangi kerugian.

Idealnya perlindungan konsumen mencakup secara seimbang kepentingan produsen dan konsumen.

The basicassumption is that commercial dealings between consumers and suppliers must weigh the legitimate interests of bothparties to be considered just and fair. An important benchmark in assessing the fairness of a transaction is the standard of parties' "reasonable expectations." This standard has evolved into one of the leading benchmarks ofEuropean consumer law. Consideration of parties' reasonable expectations sets limits to the principle offreedom of contract that defines the commercial relationship between consumers and suppliers. The momentthat a product or service does not meet the reasonable expectations of the consumer, the contract can no longer be assumedto reflect the consumer's free will to commit to the transaction. Distributive or social justice is a related rationale underlying consumer law and includes a more abstract socialpolicy motive: to increase equality and fairness in society. Governments and policy makers weighconsiderations of distributive justice and then translate these abstract goals into concrete policy measures. For example,during the German EU presidency, considerations of distributive justice served as an impetus to the adoptionof the Charter on Consumer Sovereignty in the Digital World,

\footnotetext{
${ }^{32}$ Ibid., hal. 1082-1083.
}

part of the initiative of the German Federal Ministryfor Food, Agriculture and Consumer Protection. The Charter highlighted the importance for future consumerpolicy of ensuring equal access for consumers to a diversity of cultural products and services, including respectfor the existing exemptions under copyright law. The ministry acknowledged that the protection offundamental freedoms--such as freedom of speech, freedom from discrimination, and the protection of privacy--is anew challenge for consumer policy. To this end, the Charter emphasized the need to formulate clear rightsfor consumers of digital services. ${ }^{33}$

Hakikat pemberlakukan hukum perlindungan konsumen adalah untuk menciptakan keadilan dan kewajaran dalam hubungan hukum antara produsen dan konsumen. Tidak dapat dipungkiri bahwa hubungan kedua pihak tersebut tidak berada dalam kondisi yang seimbang. Produsen lebih memiliki kekuatan tawar dengan negara karena ia memiliki kekuatan ekonomi. Konsumen besar seperti negara atau institusi lainnya mampu mengimbangi kekuatan tawar produsen, karena ia memiliki potensi ekonomi yang luar biasa. Berbeda halnya dengan konsuumen individual yang harus membangun jaringan kerja dengan sesamanya melalui media massa dan lembaga perlindungan konsumen.

Perlindungan konsumen intinya berkenaan dengan penyampaian informasi. Tujuan dari penyampaian informasi kepada konsumen adalah untuk memperbaiki otonomi dan kebebasan konsumen dalam memilih produk atau jasa. ${ }^{34}$ Idealnya, penyampaian informasi akan memberikan pemberdayaan kepada konsumen dalam hal membandingkan produk atau jasa sejenis dan memilih yang paling sesuai dengan kebutuhannya. Sebaliknya, kegagalan produsen menyampaikan informasi kepada konsumen dalam bentuk apa pun akan menghambat kemampuan konsumen untuk memilih produk atau jasa yang terbaik bagi kebutuhannya. ${ }^{35}$

Apa yang terjadi dengan kasus Antaboga Delta Sekuritas menunjukkan bahwa konsumen hanya diberikan informasi yang berkenaan dengan kepentingan perusahaan yaitu mengenai pendapatan, kelebihan produk, kemudahan yang dimiliki. ${ }^{36}$ Sebaliknya, konsumen tidak diberikan informasi mengenai risiko yang terkandung dalam produk tersebut. Konsumen juga tidak mengetahui kedudukan perusahaan dan hubungan hukumnya dengan Bank Century yang ter-

\footnotetext{
${ }^{33}$ Ibid., hal. 1082-1083.

${ }^{34}$ Ibid., hal. 1090-1091.

${ }^{35} \mathrm{Ibid} .$, hal. 1082.
} 
nyata pemilik saham PT Antaboga Delta Sekuritas. Akibatnya, ketika Bank Century mengalami masalah dan dilikuidasi, PT ADS juga terkena imbasnya yang pada akhirnya menimbulkan kerugian pada nasabah ADS.

Keterbukaan informasi berarti menyampaikan informasi sejelas mungkin. Termasuk penggunaan kata, kalimat yang jelas, besaran huruf (font).

For disclosures to be meaningful, the consumer must be able to read, understand, and appreciate the information disclosed. A real problem occurs when individuals receiving the disclosures do not understand them. This can happenfor a number of reasons - for example, everyone is familiar with the credit card disclosures printed in a font sizealmost too small to be legible. And disclosures are often written in complicated legalese. For instance, many individualsdo not understand the difference between a simple interest rate and an $A P R$. Other disclosures arevague or not written in a way that is meaningful. Although Minnesota payday lenders must post notices informingborrowers that they will pay high charges, the law does not require that these charges be disclosed as interest or as an APR. While tiny fonts and terms of art can ruin a disclosure's effectiveness, they are not the only problem. ${ }^{37}$

Keterbukaan informasi menyangkut segala aspek mulai dari waktu penyampaian, penempatan informasi, penggunaan besaran huruf, bahasa dan kalimat.

Pasar modal merupakan wahana dimana inova- si produk begitu cepat dilansir. Instrumen derivatif menjadi solusi bagi issuer untuk menjangkau calon konsumen produk pasar modal tertentu. Terdapat sejumlah hal negatif mengenai instrumen derivatif, pertama, ia disalahgunakan dan merugikan konsumen. ${ }^{38}$ Kasus instrumen sekuritas kredit perumahaan di Amerika Serikat merupakan contoh penggunaan instrumen derivatif untuk hal-hal yang merugikan pemegangnya. Teaser rate" loans were re-priced to become unaffordable. Predatory loan terms and practices-including loan flipping, fee packing, equity stripping, and steering low income and minority borrowers to expensive, unsuitable mortgage loan products-had become standard. ${ }^{39}$

\footnotetext{
${ }^{36}$ Graham, Op.cit., hal. 607.

${ }^{37}$ Kristin Siegesmund And Leah Weaver , "Minnesota Statutes Chapter 325N: A Model For Substantive Consumer Protection," William Mitchell Law Review 2006, hal. 226.

${ }^{38}$ Graham. Op.cit., hal. 607.

${ }^{39} \mathrm{Ibid}$., hal. 608
}

Kedua, kegagalan menyampaikan informasi yang relevan cenderung sebagai bentuk manipula- $\mathrm{si}^{40}$ Nasabah produk Antaboga juga tidak diberikan informasi lengkap, jelas, akurat mengenai hal-hal yang relevan seperti risiko produk, risiko hukum, risiko hubungan hukum Bank Century dengan ADS. Menilik kasus subprime mortgage di AS dan ADS di Indonesia terdapat kesamaan yaitu informasi yang tidak lengkap, tidak akurat ${ }^{41}$ merupakan penyebab fraud yang berujung pada hilangnya investasi konsumen karena kegagalan bayar issuer atas produk yang diterbitkannya.

Industri keuangan dan pasar modal pada khususnya mengandalkan kepercayaan. Kasus subprime mortgage di Amerika Serikat yang berakibat pada terjadinya krisis finansial dunia dan kasus ADS di Indonesia, walaupun tidak sampai menimbulkan krisis, namun berdampak pada kredibilitas pasar modal Indonesia. Penerapan prinsip keterbukaan dan peran otoritas di bidang keuangan dan pasar modal menjadi penting dan solusi terhadap masalah tersebut.

Harvard LawProfessor Elizabeth Warren, Chair of the Congressional Oversight Panel and an early proponent of an independentconsumer financial protection agency, explains the need for a consumer financial protectionagency in five words: "The Credit Market Is Broken." Warren says, "The broken credit marketcaused the current crisis, is perpetuating the crisis, and will cause future crises--unless we fix it." One of the most basic failures of the credit market, which could be remedied by an effective consumer financialprotection agency, results from the fact that financial products are designed to preclude meaningfulcomparison and consumer choice. Disclosures in incomprehensible terminology and fine print lure consumersto succumb to "tricks and traps." The lack of understandable credit term disclosures harmsboth individual consumers and our economy as a whole. Beyond inflicting economic damage on individualborrowers, deceptive terms in financial products negatively impact the operation of the free market system. ${ }^{42}$

Keterbukaan informasi merupakan terminologi yang debatable dari sudut pandang masing-masing pihak. Produsen memahami pelaksanaan prinsip keterbukaan informasi dalam kerangka berpikir dan kepentingannya. Konsumen tentunya menginginkan

\footnotetext{
${ }^{40}$ Ibid.

${ }^{41}$ Ibid.

${ }^{42}$ Ibid.
} 
keterbukaan informasi yang memberdayakan dirinya dalam pengambilan keputusan.

Penerapan prinsip keterbukaan informasi harus diikuti dengan regulasi dan peran otoritas. ${ }^{43}$

Disclosures are not enough. Legal terms are too abstruse even for most literate Americans. The risk/reward systemthat would regulate some lender behavior has become unhinged, providing reward for commercially unreasonableloans with virtually no risk to the lender. And the free market premise that consumers have full knowledge andfree choice is seriously flawed because of economic realities and discrimination. Vulnerable consumers need moreprotection to give them equal footing with merchants and lenders in the marketplace. ${ }^{44}$

Dua kepentingan tersebut yang harus dicakup dalam legislasi. Perdebatan mengenai penerapan prinsip keterbukaan informasi harus diselesaikan dan diformulasikan dalam hukum perlindungan konsumen.

The primary reasons why consumer protection legislation relies so heavily on disclosures instead of making substantive limits are the American faith in the free market and Americans' equal distrust of big government regulation and paternalism. When consumers are well informed, they supposedly have equal bargaining power with other market participants, such as lenders or merchants. The consumers can shop around, compare

\footnotetext{
${ }^{43}$ Dr. Stiglitz, a strong proponent of a "financial products safety commission," points out that markets fail to produce efficient outcomes when information is imperfect or asymmetric. [In his view, an independent consumer financial protection agency should require transparency in financial products, regulate incen- tives, and curb risky and exploitive practices. The third and most persuasive argument for a new, independent consumer financial protection agencyis that the existing federal agencies have fai- led to protect consumers. Allowing responsibility for consumer protection to remain where it currently resides and providing no materially different structureto assure consumer protection in the future is unacceptable to consumer protection advocates, including Committee Chairman Frank, who says:No one familiar with the track record of the bank regulatory agencies with respect to protecting consumers can deny the need for an independent agency if we are going to have effective consumer protection. Bank regulators have traditionally treated their responsibilities for consumer protection as a second priority. The existing fede-ral financial institution regulators, the Office of the Comptroller of the Currency(OCC), the Office of Thrift Supervision (OTS), the Federal Reserve Board (FRB), and the Federal Deposit Insurance Corporation (FDIC), view their primary responsibility as protecting the "safety and soundness"and profitability of their supervised institutions--an objective that can and often does conflict with consumer protection. Agency funding comes from fees and assessments on the entities supervised, resultingin mar-keting charters on the basis of ability to avoid state consumer protection laws. Agencies that possessed the legal authority to curb abusive lending practices stalled the rule making process evenas Congress pressed for action. Ibid. Hal. 610.
}

prices or interest rates, andmake the best decision, choosing to do business with one merchant and not another. This comparison shopping will influence lenders to compete for the consumers' business by offering lower rates and reduced fees and will enticemerchants to lower their prices. The market will fairly allocate risks and rewards. Further, consumers are free tomake choices. Unfortunately, various factors can interfere with the free market's regulatory influence. ${ }^{45}$

Penerapan keterbukaan informasi tidak hanya menguntungkan bagi perlindungan konsumen, tetapi juga mendorong produsen untuk menjaga kualitas barang.

\section{Kesimpulan}

1. Industri pasar modal mengandalkan kepercayaan investor. Kredibilitas pasar modal menjadi faktor konsumen menginvestasikan dananya pada produk pasar modal. Peran otoritas dalam mengawasi, membina dan melakukan penegakan hukum berkontribusi pada terciptanya pasar modal yang teratur, efisien dan wajar.

2. Penerapan prinsip keterbukaan informasi menjadi kunci bagi perlindungan konsumen produk pasar modal. Indonesia hanya perlu mengandalkan peran Otoritas Jasa Keuangan (OJK) dan YKLI serta masyarakat untuk menjaga kredibilitas pasar modal Indonesia dari fraud. Otoritas pasar modal dapat mendeteksi "keanehan" produk pasar modal melalui pemantau pelaksanaan prinsip keterbukaan, sehingga mampu mencegah kasus ADS terulang.

\section{Saran}

1. Diperlukan peran otoritas dalam mengawasi, membina dan melakukan penegakan hukum berkontribusi pada terciptanya pasar modal yang teratur, efisien dan wajar;

2. Diperlukan penerapan prinsip keterbukaan informasi menjadi kunci bagi perlindungan konsumen produk pasar modal. Indonesia hanya perlu mengandalkan peran Otoritas Jasa Keuangan (OJK) dan YKLI serta masyarakat untuk menjaga kredibilitas pasar modal Indonesia dari fraud. 
Jurnal Hukum tô-râ, Vol. 1 No. 2, Agustus 2015

\section{DAFTAR PUSTAKA}

\section{Buku:}

Bauman, Jeffrey D. "Loss And Seligman On Securities Regulation: An Essay For Don Schwartz Securities Regulation," Book Review George town Law Journal June, 1990.

Chaffee, Eric C., "A Moment Of Opportunity: Reimagining International Securities Regulation In The Shadow Of Financial Crisis," Nexus: Chapman's Journal of Law \& Policy Volume 15 2009-2010.

Chaffee, Eric C., "Contemplating The Endgame: An Evolutionary Model For The Harmonization And Centralization Of International Securities Regulation," University of Cincinnati Law Review Volume 79 Winter 2010.

Elosta, Jared. "Dynamic Federalism And Consumer Financial Protection: How The Doddfrank Act Changes The Preemption Debate," Recent Development, North Carolina Law Review May, 2011.

Graham, Ann. "The Consumer Financial Protection Agency: Love It Or Hate It, U.S. Financial Regulation Needs It,“ Article, Symposium: Financial Regulatory Reform: Genesis, Progress, and Impact, Villanova Law Review 2010.

Harris, Lee. "A Critical Theory Of Private Equity," Article Delaware Journal of Corporate Law2010. Helberger, Natali. and P. Bernt Hugenholtz, "No Place Like Home For Making A Copy: Private Copying

In European Copyright Law And Consumer Law," Article Symposium: Copyright, Digital Rights

Management Technology, and Consumer Protection, Berkeley Technology Law Journal Summer

2007. Husein, Yunus. Privasi Versus Kepentingan Umum, Program Pascasarjana, Fakultas Hukum,

Universitas

Indonesia, 2003.

Levitin, Adam J." Hydraulic Regulation: Regulating Credit Markets Upstream," Yale Journal on Regulation Summer 2009.

Levitin, Adam J. “The Consumer Financial Protection Agency,”American Bankruptcy Institute Journal October, 2009.

Ma, Jingyun.Fengming Song, Zhishu Yang," The DualRole OfThe Government: Securities Market Regulationin China 1980-2007, Journal of Financial Regulation and Compliance Volume 18, 2010.

Nasution. Bismar, Keterbukaan Dalam Pasar Modal Indonesia, Program Pascasarjana Fakultas Hukum Universitas Indonesia, 2001.

Rose, Caspar. "The Challenges Of Quantifying Investor Protection In A Comparative Context," European Business Organization Law Review Vol. 82007.

Siegesmund, Kristin. And Leah Weaver, "Minnesota Statutes Chapter 325N: A Model For Substantive Consumer Protection," William Mitchell Law Review 2006.

Sparrow, Malcolm K. The Regulatory Craft: Controlling Risks, Solving Problems And Managing Compliance, Washington D.C.,: Brookings Institution Press, 2000

Torneden, Roger L. "Will Devaluation Of Dollar Pull The U.S. Out Of Depression Once Again?” The 80th Anniversary of the Great Crash of 1929:

Law, Markets and the Role of the State, Nexus: Chapman's Journal of Law \& Policy Volume 
15, 2009-2010.

Worrell, Kyle C. "Crisis As ACatalyst For Federal Regulation In Financial Markets: The Rise Of The Consumer Financial Protection Bureau," Article Citizens Divided on Citizens United: Campaign Finance Reform and the First Amendment Nexus: Chapman's Journal of Law \& Policy 20102011.

Undang-Undang:

Undang-Undang RI Nomor 8 Tahun 1999 Tentang Perlindungan Konsumen. Lembaran Negara Nomor 42. 